\title{
A tribo Miconieae (Melastomataceae) no Parque Estadual do Biribiri, Diamantina, Minas Gerais, Brasil
}

\author{
The Miconieae tribe (Melastomataceae) in the Parque Estadual do Biribiri, \\ Diamantina, Minas Gerais, Brazil
}

Inara Montini Araújo ${ }^{1,3}$ \& Rosana Romero ${ }^{2}$

\begin{abstract}
Resumo
A tribo Miconieae no Parque Estadual do Biribiri está representada por 23 espécies e cinco gêneros. Miconia é o gênero mais numeroso, com 14 espécies, seguido de Leandra com quatro, Clidemia com três e Tococa e Ossaea com uma espécie cada. As espécies ocorrem na maioria das fitofisionomias do parque, com um maior número de espécies nas formações florestais. Chave de identificação para as espécies, descrições e dados de distribuição geográfica são fornecidos, assim como ilustrações dos táxons pouco representados na literatura. Palavras-chave: Clidemia, Leandra, Miconia, Ossaea, Serra do Espinhaço, Tococa.
\end{abstract}

\begin{abstract}
The Miconieae tribe is represented by 23 species and five genera in the Parque Estadual do Biribiri. Miconia is the largest genus, with 14 species, followed by Leandra with four, Clidemia with three, Tococa and Ossaea with one species each. Species occur in almost vegetation types in the park, with a larger number of species occurring in forests. Identification key for the species, descriptions, and geographic distribution data are provided, as well as illustrations for the taxon poorly illustrated in the literature.
\end{abstract}

Key words: Clidemia, Leandra, Miconia, Ossaea, Espinhaço Range, Tococa.

\section{Introdução}

Melastomataceae Juss. apresenta aproximadamente 4.500 espécies distribuídas em 166 gêneros (Renner 1993), com a maioria delas ocorrendo nas regiões tropicais e subtropicais. As espécies são encontradas em áreas montanhosas até florestas de planície, savanas e em vegetações perturbadas (Renner 1993; Clausing \& Renner 2001). No Brasil, a família está representada por 1.370 espécies em 66 gêneros (Baumgratz et al. 2015).

Atualmente são reconhecidas 10 tribos (Renner 1993; Penneys et al. 2010), sendo Miconieae considerada uma das maiores, com 19-23 gêneros e cerca de 1.800 espécies (Michelangeli et al. 2008). Estudos filogenéticos indicam que pelo menos três gêneros (Bellucia Raf., Henriettea DC. e Kirkbridea Wurdack), anteriormente incluídos em Miconieae, são reconhecidos na tribo Henrietteeae (Michelangeli et al. 2004; Penneys et al. 2010), enquanto que
Huilaea Wurdack e Chalybea Naudin estão melhor posicionados em Blakeeae Bentham \& Hooker (Penneys \& Judd 2011). Apesar das mudanças recentes, a delimitação de alguns gêneros de Miconieae ainda permanece incerta, principalmente com relação aos gêneros mais numerosos, como Clidemia D. Don, Leandra Raddi, Miconia Ruiz \& Pav. e Ossaea DC., os quais não se mostram monofiléticos (Michelangeli et al. 2004; Goldenberg et al. 2008; Martin et al. 2008).

De um modo geral, Melastomataceae tem sido alvo de estudos em diversas localidades do estado de Minas Gerais (Romero 1996; Romero \& Martins 2002; Matsumoto \& Martins 2005; Kinoshita et al. 2007; Silva \& Romero 2008; Barbarena et al. 2010), com alguns realizados em áreas da Serra do Espinhaço (Semir et al. 1987; Candido 2005; Martins et al. 2009; Rolim 2011). Estes últimos correspondem a inventários feitos na

\footnotetext{
'Universidade Federal de Uberlândia, Pós-graduação em Biologia Vegetal, Inst. Biologia, R. Ceará s.n., 38400-902, Uberlândia, MG, Brasil.

${ }^{2}$ Universidade Federal de Uberlândia, Inst. Biologia, R. Ceará s.n., 38400-902, Uberlândia, MG, Brasil.

${ }^{3}$ Autora para correspondência: inaramontini@gmail.com
} 
porção mineira da Serra do Espinhaço e revelam a diversidade da tribo Miconieae, com pelo menos 91 espécies distribuídas em praticamente todas as fisionomias, havendo, contudo, predomínio nas formações florestais.

Até recentemente a flora do Parque Estadual do Biribiri (PEB) era pouco conhecida, porém nos últimos anos, vem sendo alvo de inventários de importantes famílias de Angiospermas (Andrino 2013; Montini 2013; Franco et al. 2014; Marques \& Nakajima 2015), mostrando a alta diversidade da área. Dando continuidade aos estudos no parque, o presente trabalho apresenta o tratamento taxonômico da tribo Miconieae, fornecendo chave analítica de identificação para as espécies, descrições morfológicas, ilustrações e dados de distribuição geográfica.

\section{Material e Métodos}

O PEB (Fig. 1) está situado na região do alto vale do rio Jequitinhonha, no complexo da Serra do Espinhaço, a sudeste do município de Diamantina (IEF 2004). Com área de aproximadamente 17 mil ha, é limitado a noroeste pela comunidade de Pinheiros e a leste/nordeste pelo distrito de Mendanha (IEF 2004).

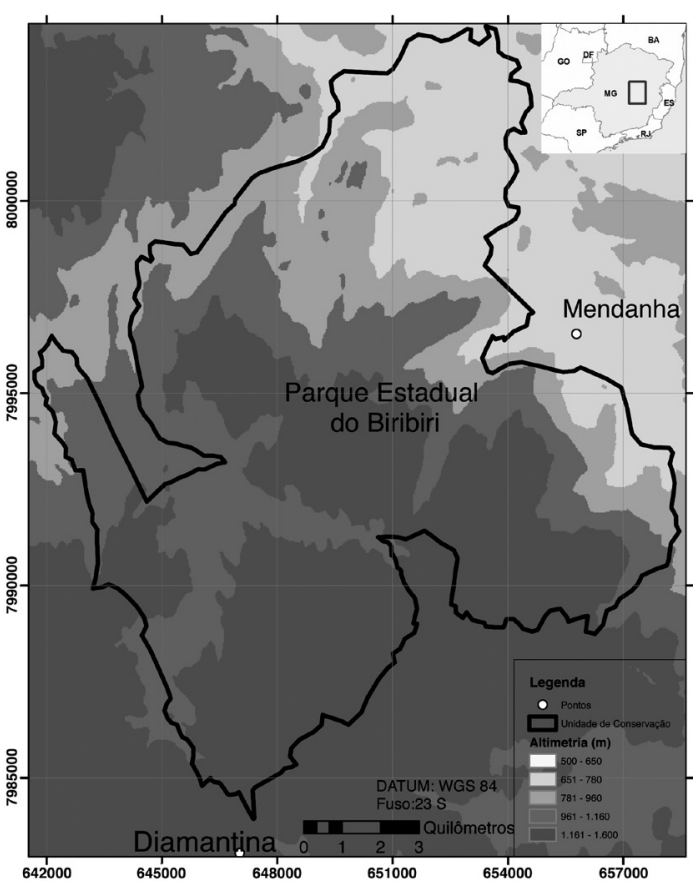

Figura 1 - Mapa do Parque Estadual do Biribiri, Diamantina, Minas Gerais, Brasil.

Figure 1 - Map of Parque Estadual do Biribiri, Diamantina, Minas Gerais, Brazil.
A vegetação do $\mathrm{PEB}$, inserida no domínio Cerrado, abrange fitofisionomias de campo rupestre (predominante no parque), campo limpo, campo sujo, campo sujo úmido, campo limpo úmido, cerrado rupestre, cerrado típico, cerrado denso, cerrado ralo, cerradão, mata ciliar, mata de galeria e mata seca semidecídua, de acordo com a classificação proposta por Ribeiro \& Walter (2008).

As descrições da tribo, dos gêneros e das espécies foram baseadas nos materiais provenientes do Parque Estadual do Biribiri (PEB), depositados nos herbários BHCB, DIAM SPF e UEC e nas coleções feitas no parque em 2011 e 2012, depositadas no herbário HUFU, com duplicatas nos herbários BHCB, DIAM, RB, SPF e UEC (siglas de acordo com Thiers, continuamente atualizado). A identificação dos táxons de Miconieae foi feita com base em Cogniaux (1883-1885, 1886-1888) e Goldenberg (2000).

A terminologia morfológica seguiu Radford (1986). Para táxons desprovidos de flores, utilizou-se material adicional proveniente de outras localidades para a descrição das partes florais. Devido o volume de material examinado, foi citado apenas um material selecionado para cada espécie. A lista dos coletores e os respectivos herbários são apresentados ao final do texto.

A maioria das espécies encontra-se parcial ou totalmente ilustrada na literatura e por isso, optouse por ilustrar apenas aquelas com algum grau de endemismo e/ou que não se encontram ilustradas na literatura.

\section{Resultados e Discussão}

A família Melastomataceae está representada no PEB por 98 espécies distribuídas em 23 gêneros (Montini 2013). Microlicieae Naudin é a tribo mais representativa com 48 espécies e Microlicia D.Don o gênero mais numeroso, com 28 espécies. Melastomeae Renner apresenta 23 espécies, com Tibouchina Aubl. representado por 11 espécies. Miconieae apresenta 23 espécies, distribuídas nos gêneros Miconia Ruiz \& Pav. (14 espécies), Leandra Raddi (quatro espécies), Clidemia D.Don (três espécies), Ossaea DC. e Tococa Aubl. (uma espécie cada). A tribo Merianieae está representada apenas por Huberia piranii Baumgratz e Merianthera sipolisii (Glaz. \& Cogn.) Wurdack.

Representantes de Miconieae ocorrem em praticamente todas as fisionomias do PEB, com predomínio nas formações florestais. A maioria dos táxons encontrados no Biribiri apresenta ampla distribuição geográfica. Apenas Miconia paradoxa 
(DC.) Triana apresenta distribuição restrita ao estado de Minas Gerais, tendo sido registrada, até o momento, ao longo da porção mineira do Espinhaço.

\section{Tratamento taxonômico}

\section{Miconieae Triana.}

Subarbustos, arbustos, arvoretas ou árvores. Ramos subcilíndricos, cilíndricos, quadrangulares ou alados, glabros ou pilosos. Folhas pecioladas, glabras ou geralmente pilosas. Inflorescências em panículas, tirsos ou cimeiras, terminais, laterais ou axilares. Flores 4-6-meras; hipanto geralmente piloso, raramente glabro, campanulado, cilíndrico ou urceolado; sépalas geralmente curtas, triangulares ou muito reduzidas. Estames 8-12, frequentemente isomorfos, mais raramente dimorfos ou desiguais no tamanho, glabros, anteras de formatos variados, ápice com 1-4 poros, apicais, às vezes poro longitudinal amplo semelhante uma rima, conectivo pouco ou não prolongado, inapendiculado ou apêndice inconspícuo. Ovário 3-5-locular, ínfero ou parcialmente ínfero, ápice piloso ou glabro, estigma captado, punctiforme ou truncado. Fruto baga. Sementes ovais, arredondadas ou obpiramidais.

Miconieae é uma das maiores tribos de Melastomataceae, com distribuição exclusivamente neotropical (Michelangeli et al. 2008), cujos representantes são caracterizados, principalmente, pelo ovário ínfero ou parcialmente ínfero, frutos do tipo baga e estames inapendiculados ou com apêndices curtos (Michelangeli et al. 2008).

\section{Chave de identificação para as espécies de Miconieae no Parque Estadual do Biribiri}

1. Um par de formicários na base da folha.

5. Tococa guianensis



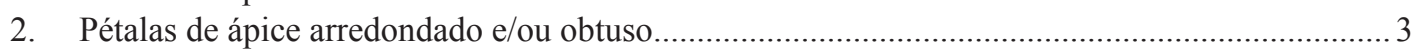

3. Inflorescência pseudo-axilar, raro também terminal; ovário 5-locular .................................. 4

4. Ramos e folhas desprovidos de tricomas glandulares; ovário glabro

1.2. Clidemia hirta

4'. Ramos e folhas com tricomas glandulares; ovário com tricomas glandulares no ápice .

5. Face adaxial da folha revestida por tricomas glandulares; folhas e ramos com tricomas glandulares providos de conteúdo amarelo-esverdeado

1.3. Clidemia urceolata

5'. Face adaxial da folha revestida por tricomas setosos; folhas e ramos com tricomas glandulares providos de conteúdo de outra cor, não amarelo-esverdeado .

1.1. Clidemia capitellata

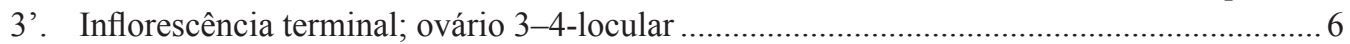

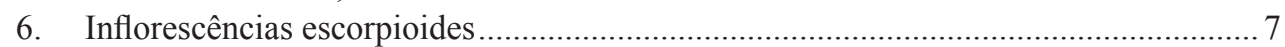

7. Face abaxial das folhas revestida por tricomas aracnoides

3.1. Miconia albicans

7'. Face abaxial das folhas revestida por tricomas estrelados ............................... 8

8. Ramos basais engrossados, robustos ........................3.7. Miconia ferruginata

8'. Ramos basais delgados........................................................................ 9

9. Dois pares de nervuras acródromas, par mais interno $3,5-5 \mathrm{~mm}$ suprabasal ................................................................ Miconia elegans

9'. Dois pares de nervuras acródromas basais ......................................... 10

10. Folha oblongo-elíptica a oval; antera amarela posteriormente vinácea.

3.13. Miconia stenostachya

10'. Folha lanceolada a oblongo-lanceolada; antera branca

3.4. Miconia cubatanensis

6'. Inflorescências não escorpioides

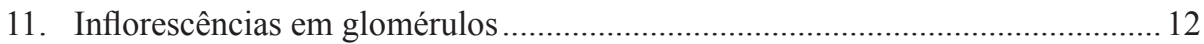

12. Base da folha cordada

3.2. Miconia alborufescens

$12^{\prime}$. Base da folha arredondada ou atenuada. 
13. Margem da folha sinuosa, levemente revoluta; flores tetrâmeras .

13'. Margem da folha denteado-ciliada; flores pentâmeras.

3.12. Miconia sclerophylla

1'. Inflorescências não em glomérulos 3.8. Miconia ibaguensis

14. Plantas totalmente glabras.

3.3. Miconia chamissois

14'. Plantas revestidas por tricomas, persistentes ou caducos.. 15

15. Ramos basais decorticantes; anteras com um poro longitudinal amplo, semelhante a uma rima, correspondendo a mais de $90 \%$ do comprimento da teca.

3.11. Miconia rimalis

15'. Ramos basais não decorticantes; anteras com 1-4 poros restritos ao ápice da teca ........

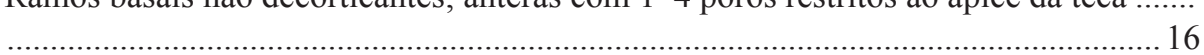

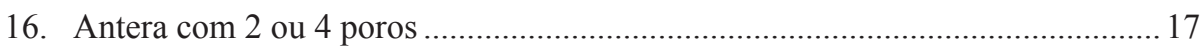

17. Subarbustos; folha de margem inteira ou sinuosa; anteras 2-porosas .............. 3.5. Miconia cyathanthera

17'. Arvoretas; folha com metade superior da margem denticulada; anteras 4-porosas

3.14. Miconia theizans

16'. Antera com um poro 18

18. Ramos decussadamente achatados e alados; estames inapendiculado.

3.10. Miconia paradoxa

18'. Ramos subcilíndricos; estames apendiculados.........3.9. Miconia ligustroides

2'. Pétalas de ápice agudo .

19. Inflorescência axilar; conectivo apendiculado

19'. Inflorescência terminal; conectivo inapendiculado

4. Ossaea congestiflora

20. Folha de base arredondada a subcordada ou cordada, com nervuras acródromas basais

21. Ramos revestidos por tricomas setosos e vilosos, $0,5-1 \mathrm{~mm}$ compr.

2.1. Leandra aurea

21'. Ramos revestidos por tricomas hirsutos, 2-7 mm compr. ........2.2. Leandra cancellata

20 '. Folha de base atenuada, com pelo menos um par de nervuras suprabasais

22. Face adaxial da folha bulada, revestida por tricomas estrigosos, face abaxial foveolada, revestida por tricomas setosos e vilosos; flores 6-meras.

2.3. Leandra melastomoides

22'. Face adaxial da folha plana, revestida por tricomas glandulares sésseis, entremeados por esparsos tricomas estrelados, face abaxial revestida por tricomas glandulares sésseis e com tricomas setosos na base das nervuras primárias; flores 5-meras.

2.4. Leandra quinquedentata

\section{Clidemia D.Don.}

Subarbustos ou arbustos, indumento variado, ramos cilíndricos. Folhas ovais, $2-3$ pares de nervuras acródromas basais; ausência de um par de formicários na base da folha. Panículas pseudo-axilares, raro também terminais. Brácteas e bractéolas persistentes ou caducas. Flores 5-meras, sésseis ou pediceladas; hipanto urceolado, piloso; sépalas persistentes, dentes externos geralmente maiores em comprimento que os limbos internos; corola alva ou branco-translúcida, pétalas oblongas ou obovais, ápice arredondado e/ou obtuso, glabras; estames 10, alvos ou cremes, isomorfos, antera subulada, 1 poro apical, conectivo não prolongado abaixo das tecas, inapendiculado ou apendiculado; ovário 5-locular, ínfero ou parcialmente ínfero, ápice piloso ou glabro; estilete filiforme, glabro, estigma truncado. Bagas jovens verdes, maduras verdes a arroxeadas; sementes ovais.

1.1. Clidemia capitellata (Bonpl.) D.Don, Mem. Wer. Nat. Hist. Soc. 4(2): 310. 1823.

Subarbustos, 0,5-1,5 m alt. Ramos, pecíolo, face abaxial das brácteas, bractéolas e folhas, revestidos de tricomas dendríticos, setosos e glandulares, estes providos de conteúdo de outra cor, não amarelo-esverdeado. Folhas com pecíolo 0,5-1,2 cm compr.; lâmina 3,5-9,5 × 1,5-6,5 cm, 
cartácea a membranácea, oval, ápice acuminado, base arredondada, margem denteada, ciliada, face adaxial bulada, revestida por tricomas setosos, face abaxial foveolada. Panícula pseudo-axilar, ca. $6,5 \mathrm{~cm}$ compr.; brácteas ca. $4 \times 0,5 \mathrm{~mm}$, lineares, ápice agudo, face adaxial glabra; bractéolas ca. $1,5 \times 1 \mathrm{~mm}$, arredondadas, ápice agudo, face adaxial glabra. Flores sésseis; hipanto ca. 3 $\times 3 \mathrm{~mm}$, drevestido por tricomas dendríticos, entremeados por esparsos tricomas setosos; limbo interno da sépala ca. 2,5 × $2 \mathrm{~mm}$, membranáceo, arredondado, face abaxial revestida por tricomas dendríticos e entremeada por esparsos tricomas setosos, face adaxial glabra, margem ciliada, dente externo da sépala ca. $3 \times 0,5 \mathrm{~mm}$, linear, ápice agudo, revestido por tricomas setosos e entremeados por esparsos tricomas dendríticos; pétalas ca. 4,5 × 3,5 mm, branco-translúcidas, oblongas, ápice obtuso; estames alvos, filete ca. 2 mm compr., antera ca. 2,5 mm compr., subulada, espessada na base, conectivo giboso no dorso; ovário ínfero, ápice terminado por um tricoma glandular; estilete ca. 6,5 mm compr. Bagas ca. $5 \times 5 \mathrm{~mm}$, verdes a arroxeadas, sementes ca. 0,6 $\times 0,6 \mathrm{~mm}$.

Material selecionado: Estrada para vila do Biribiri, ponte do João de Barro, 13.III.2012, fl. e fr., I.M. Araújo et al. 227 (HUFU).

Clidemia capitellata ocorre em todas as regiões do Brasil (BFG 2015). No PEB é encontrada em campo rupestre, mais frequentemente em áreas antropizadas. Semelhante a C. urceolata DC., que também ocorre no parque, principalmente pelo tipo de hábito, forma e dimensões das folhas, contudo é fácil distingui-las no campo principalmente pelo conteúdo de coloração amarelo-esverdeado presente nos ramos e folhas de C. urceolata.

Ilustração em Martins et al. (2009), Figura 1g-h.

1.2. Clidemia hirta (L.) D.Don, Mem. Wern. Nat. Hist. Soc. 4(2): 309. 1823.

Subarbustos, 0,5-1 m alt.; Ramos, pecíolo, brácteas, hipanto e dentes externos das sépalas, revestidos por tricomas hirsutos e entremeados por esparsos tricomas estrelados, tricomas glandulares ausentes. Ramos apicais caniculados. Folhas com pecíolo 0,5-1,5 cm compr.; lâmina 4-11,5 $\times 2-6 \mathrm{~cm}$, membranácea, oval, ápice acuminado, base arredondada a levemente cordada, margem crenulada, ciliada, revestidas por tricomas setosos, par marginal de nervuras acródromas inconspícuo. Panículas pseudo-axilares, raro também terminais ca. $2 \mathrm{~cm}$ compr.; brácteas ca. $4 \times 1 \mathrm{~mm}$, lineares, ápice agudo. Flores com pedicelo ca. 2,5 mm compr.; hipanto ca. $4 \times 3 \mathrm{~mm}$; limbo interno da sépala ca. $1 \times 0,5 \mathrm{~mm}$, triangular, ápice agudo, dente externo ca. $3 \times 0,5 \mathrm{~mm}$, linear, ápice agudo; pétalas ca. $5,5 \times 3,5 \mathrm{~mm}$, alvas, obovais, ápice arredondado; estames alvos, filete ca. 2,5 mm compr., antera ca. $4 \mathrm{~mm}$ compr., subulada, conectivo com apêndice dorsal ca. $0,5 \mathrm{~mm}$ compr.; ovário 1/2-ínfero, glabro; estilete ca. $5 \mathrm{~mm}$ compr. Bagas imaturas ca. 7,5 ×5 mm, verdes; sementes imaturas ca. $0,5 \times 0,3 \mathrm{~mm}$.

Material selecionado: Local não indicado, 14.II.2001, fl. e fr., J.R. Stehmann et al. 2795 (SPF).

Clidemia hirta ocorre desde o México até o Sul do Brasil (Goldenberg et al. 2005), estando representada em todas as regiões do país (BFG 2015). No PEB é pouco comum, ocorrendo exclusivamente em campo rupestre. É facilmente distinguida das demais espécies de Clidemia na área, principalmente pelos ramos revestidos por tricomas hirsutos, entremeados por esparsos tricomas estrelados, tricomas glandulares ausentes, além do ovário glabro.

Ilustração em Goldenberg et al. (2005), Figuras 9-10.

1.3. Clidemia urceolata DC., Prodr. 3: 158. 1828. Arbustos, 0,5-1,5 m alt. Ramos, pecíolo e face abaxial das folhas, revestidos por tricomas dendríticos, entremeados por esparsos tricomas setosos e glandulares, estes liberando conteúdo de coloração amarelo-esverdeado nas folhas e ramos. Folhas com pecíolo 0,3-2 cm compr.; lâmina 3-11 $\times$ 1,5-6,5 cm, cartácea, oval, ápice acuminado, base arredondada a cordada, margem denteada, ciliada, face adaxial bulada, revestida por tricomas glandulares, face abaxial foveolada, par marginal de nervuras acródromas inconspícuo. Panículas pseudo-axilares ca. 5,5 cm compr.; bractéolas 3,5-4,5 × ca. $1 \mathrm{~mm}$, lineares, face abaxial revestida por tricomas estrelados entremeados por esparsos tricomas setosos e glandulares. Flores sésseis; hipanto $4-4,5 \times$ ca. $3 \mathrm{~mm}$, revestido por tricomas estrelados entremeados por tricomas glandulares; limbo interno da sépala ca. $3 \times 1,5 \mathrm{~mm}$, membranáceo, arredondado, face abaxial revestida por tricomas estrelados, face adaxial glabra, margem ciliado-glandulosa, dente externo da sépala ca. 1,5 ×0,5 mm, triangular, ápice agudo, revestido por tricomas setosos, entremeados por tricomas estrelados; pétalas 3,5-5 × ca. $2,5 \mathrm{~mm}$, alvas, oblongas a obovais, 
ápice arredondado a obtuso; estames cremes, filete ca. $3 \mathrm{~mm}$ compr., antera ca. 2,5 mm compr., subulada, conectivo inapendiculado; ovário ínfero, ápice moderadamente revestido por tricomas glandulares; estilete ca. $5 \mathrm{~mm}$ compr. Bagas ca. $5 \times 3,5 \mathrm{~mm}$, verdes a arroxeadas; sementes ca. 1 $\times 0,5 \mathrm{~mm}$.

Material selecionado: Duas Pontes, 14.XII.2011, fl., I.M. Araújo et al. 194 (HUFU).

Clidemia urceolata ocorre desde a América Central até o sul do Brasil (Goldenberg et al. 2005). No PEB, ocorre em campo rupestre e mais comumente em áreas antropizadas. Pode ser reconhecida pelas folhas ovais e tricomas glandulares com conteúdo amarelo-esverdeado nas folhas e ramos.

Ilustrações em Matsumoto \& Martins (2005), Figuras 11-13, e Silva \& Romero (2008), Figura 2e.

\section{Leandra Raddi.}

Subarbustos a arvoretas, indumento variado, ramos cilíndricos. Folhas com 2-3 pares de nervuras acródromas basais e/ou suprabasais; ausência de um par de formicários na base da folha. Panículas ou tirsos, terminais. Brácteas e bractéolas lanceoladas, ápice agudo, persistentes ou caducas. Flores 5-6 meras, sésseis ou pediceladas; hipanto campanulado, cilíndrico ou urceolado, piloso; corola alva ou branco-translúcida, pétalas lanceoladas, oblongo-lanceoladas ou ovaloblongas, glabras, ápice agudo, piloso ou não; estames 10-12, vináceos, alvos ou cremes, iguais ou levemente desiguais em tamanho, antera atenuada ou oblonga, 1 poro apical, conectivo prolongado ou não abaixo das tecas, inapendiculado; ovário 3-locular, parcialmente ínfero, ápice piloso ou glabro; estilete filiforme, glabro, estigma punctiforme. Bagas jovens verdes, maduras nigrescentes, sementes obpiramidais.

2.1. Leandra aurea (Cham.) Cogn. in Martius, Eichler \& Urban, Fl. bras. 14(4): 142. 1886.

Subarbustos a arvoretas, 1-3 m alt. Ramos revestidos por tricomas setosos e vilosos, $0,5-1$ $\mathrm{mm}$ compr., entremeados por esparsos tricomas dendríticos; ramos com aspecto aveludado, os mais jovens com tricomas alvos. Folhas com pecíolo $0,5-2,5 \mathrm{~cm}$ compr., mesmo indumento dos ramos; lâmina 3,5-13 × 1,5-7 cm, membranáceocartácea a coriácea, lanceolada a oval, ápice agudo, raramente acuminado, base arredondada a cordada, margem inteira a crenulada, ciliada, face adaxial bulada ou não, esparsa a densamente revestida por tricomas setosos ou estrigosos, face abaxial foveolada ou não, revestidas por tricomas vilosos, entremeados por esparsos tricomas estrelados ou revestidas somente por tricomas estrelados, 2-3 pares de nervuras acródromas basais. Panículas 6,5-16 cm compr.; bractéolas ca. 4,7 × 1,4 mm, face adaxial glabra, face abaxial revestida por tricomas setosos. Flores 5-meras, sésseis; hipanto $3,5-4 \times 2,5-3,5 \mathrm{~mm}$, cilíndrico, revestido por tricomas hirsutos, entremeados por esparsos tricomas dendríticos; limbo interno da sépala membranáceo, margem dendrítico-ciliada, ápice arredondado, dente externo da sépala 1,5-2,5 $\times$ $0,5-1 \mathrm{~mm}$, triangular, ápice agudo, revestido por tricomas hirsutos; pétalas 3,5-5 × 1,5-2,5 mm, branco-translúcidas, oval-oblongas; estames 10 , iguais, vináceos, filete ca. $3,5 \mathrm{~mm}$ compr., antera 2,5-3,5 mm compr., atenuada no ápice, conectivo não prolongado abaixo das tecas, espessado na base; ovário 1/2-ínfero, ápice viloso; estilete 7-8,5 $\mathrm{mm}$ compr. Bagas globosas, 5,5-8,5 × 5-5,5 mm, nigrescentes; sementes ca. $1 \times 0,5 \mathrm{~mm}$.

Material selecionado: Alto da mãe Rita, fundo da casa dos ventos, 27.VI.2012, fl. e fr., I.M. Araújo et al. 324 (HUFU).

Leandra aurea apresenta ampla distribuição, ocorrendo no Brasil, desde a Bahia ao Rio Grande do Sul (BFG 2015), e também na Bolívia (Martins et al. 2009). No PEB é frequente em quase todas as fitofisionomias. Na área de estudo, foram observados indivíduos correspondentes à circunscrição de L. aurea (Cogniaux 1886-1888), outros correspondentes à L. lacunosa (Cogniaux 1886-1888) e indivíduos com características intermediárias entre estas espécies. Souza \& Baumgratz (2009), ao analisarem um grande número de espécimes, também encontraram indivíduos com características intermediárias entre $L$. aurea e $L$. lacunosa. Provavelmente, $L$. lacunosa seja um sinônimo de L. aurea, contudo a sinonimização desta espécie só poderá ser proposta após análise da coleção-tipo.

Ilustrações em Matsumoto \& Martins (2005), Figuras 18-20; Silva \& Romero (2008), Figura 2j-k.

2.2. Leandra cancellata Cogn. in Martius, Eichler \& Urban, Fl. bras. 14(4): 103. 1886.

Fig. $2 \mathrm{j}-\mathrm{k}$

Subarbustos, 0,5-1,5 m alt. Ramos, pecíolo e hipanto revestidos por tricomas hirsutos, 2-7 $\mathrm{mm}$ compr., entremeados por esparsos tricomas dendríticos. Folhas com pecíolo $0,5-2 \mathrm{~cm}$ compr.; lâmina 5-11 × 1,5-3,5 cm, cartáceo-coriácea, 


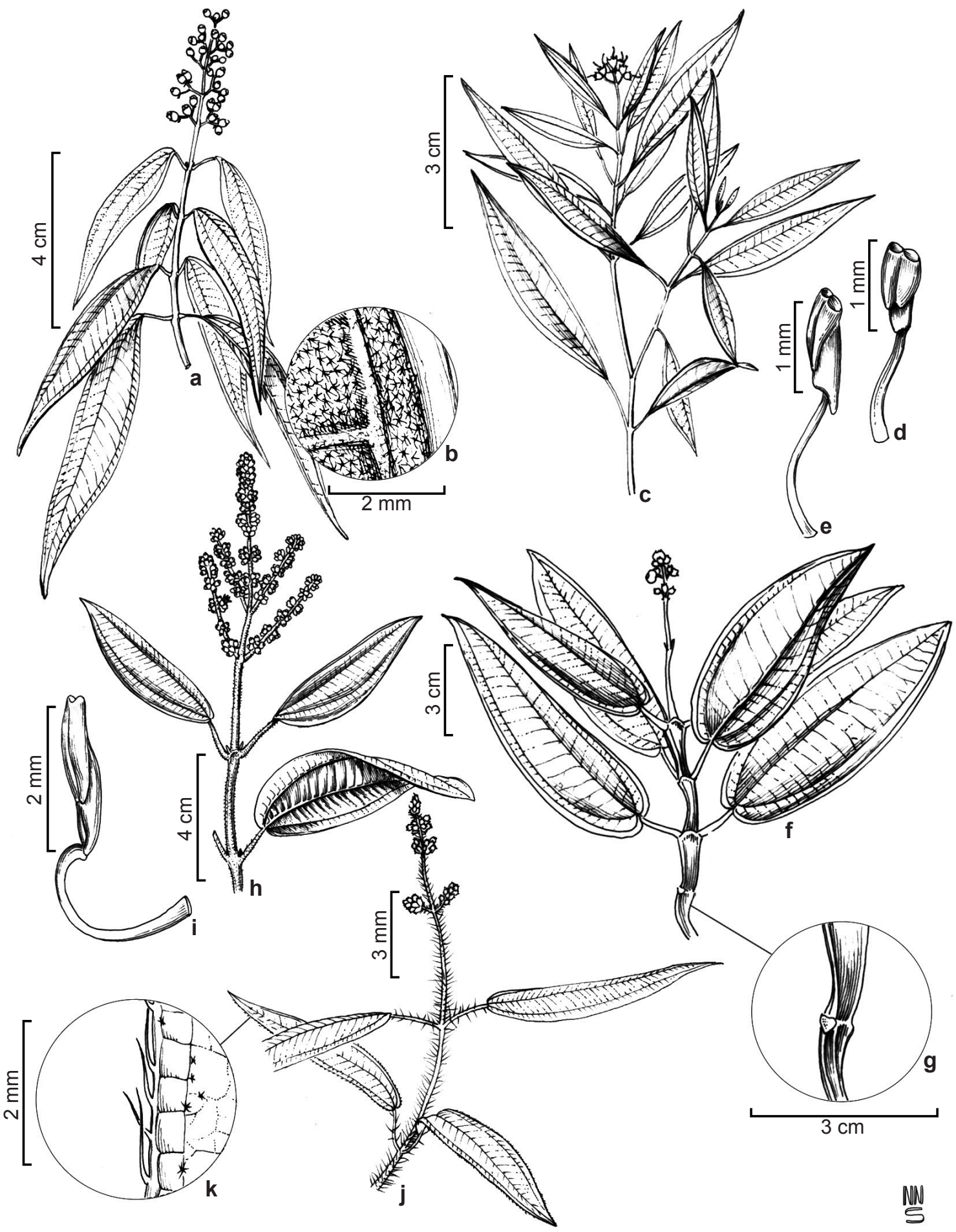

Figura 2 - a-b. Miconia cubatanensis Hoehne-a. ramo florífero; b. detalhe do indumento estrelado-tomentoso na face abaxial da folha. c-e. Miconia cyathanthera Triana -c. ramo florífero; d. estame antepétalo; e. estame ante-sépalo. f-g. Miconia paradoxa (DC.) Triana -f. ramo florífero; g. detalhe do ramo. h-i. Miconia sclerophylla Triana-h. ramo florífero; i. estame. j-k. Leandra cancellata Cogn. - j. ramo florífero; k. detalhe da margem setoso-ciliada da folha com tricomas estrelados na face abaxial. Figure 2 - a-b. Miconia cubatanensis Hoehne - a. branch; b. detail of stellate indument on abaxial surface of leaf. c-e. Miconia cyathanthera Triana - c. branch, D. small stamen; e. large stamen. f-g. Miconia paradoxa (DC.) Triana-f. branch; g. detail of the branch. h-i. Miconia sclerophylla Triana - h. branch; i. stamen. $\mathrm{j}-\mathrm{k}$. Leandra cancellata Cogn. $-\mathrm{j}$. branch; $\mathrm{k}$. detail of stellate trichomes on the abaxial surface of leaf and leaf margin ciliate. 
lanceolada ou lanceolado-oval, ápice agudo, base arredondada a subcordada, margem inteira a crenulada, setoso-ciliada, levemente revoluta ou não, face adaxial lisa ou bulada, esparsamente revestida por tricomas estrelados ou estrigosos, face abaxial foveolada, revestida por esparsos tricomas hirsutos nas nervuras e estrelados na lâmina, 2 pares de nervuras acródromas basais. Panículas $8-16,5 \mathrm{~cm}$ compr.; brácteas ca. $3,5 \times 1 \mathrm{~mm}$, lanceoladas, ápice agudo, terminado em um tricoma setoso, glabras, margem dendrítico-ciliada; bractéolas ca. 1,5 $\times$ $0,5 \mathrm{~mm}$, semelhantes às brácteas. Flores 5 -meras, sésseis ou pediceladas; pedicelo ca. $1 \mathrm{~mm}$ compr.; hipanto 3,2-5 × 2,5-3,5 mm, campanulado; limbo interno da sépala inconspícuo, dente externo da sépala 1,5-3 × 0,5-1 mm, linear-subulado, revestidos por tricomas hirsutos; pétalas 3-3,8 $\times$ 1,0-1,5 mm, branco-translúcidas, lanceoladas, ápice agudo; estames 10, iguais ou levemente desiguais no tamanho, cremes, filete $3,5-4 \mathrm{~mm}$ compr., antera ca. $2,5 \mathrm{~mm}$ compr., atenuada no ápice, conectivo não prolongado abaixo das tecas; ovário 3/4- ou 1/2-ínfero, ápice setoso ou glabro; estilete 5-8,5 mm compr. Bagas globosas ca. 6,5 $\times 4,5 \mathrm{~mm}$, castanhas, sementes ca. 1,5 $\times 0,7 \mathrm{~mm}$. Material selecionado: Alto das Mangueiras, 15.XII.2011, fl., I.M. Araújo et al. 210 (HUFU).

Leandra cancellata ocorre nos estados da Bahia, Minas Gerais e Rio de Janeiro (BFG 2015). No PEB é frequente em campo rupestre, cerrado rupestre, mata seca semidecídua, mata de galeria e em áreas antropizadas. Pode ser reconhecida pelas folhas lanceoladas ou lanceolado-ovais e os ramos revestidos por tricomas hirsutos $2-7 \mathrm{~mm}$ compr., entremeados por esparsos tricomas dendríticos.

Ilustração em Cogniaux (1886-1888), Figura 22.

2.3. Leandra melastomoides Raddi, Mem. Mat. Fis. Soc. Ital. Sci. Modena, Pt. Mem. Fis. 18: 386. 1820.

Arbustos, ca. 2,5 m alt. Ramos apicais, face adaxial das folhas e das bractéolas revestidos por tricomas estrigosos, ramos basais glabrescentes, hipanto, face adaxial do limbo e do dente das sépalas revestidos por tricomas setosos. Folhas com pecíolo $0,6-1,5 \mathrm{~cm}$ compr., mesmo indumento dos ramos apicais; lâmina 4-16 × 2,5-4 cm, cartácea, lanceolada, ápice agudo, base atenuada, margem sinuosa, face adaxial bulada, face abaxial foveolada, revestida por tricomas setosos e vilosos, 2 pares de nervuras acródromas, par mais interno ca. 13,5 mm suprabasal. Panículas de glomérulos 8-11 cm compr.; bractéolas $5-6,5 \times$ ca. $2,5 \mathrm{~mm}$, lanceoladas, ápice agudo, face abaxial glabra. Flores 6-meras, sésseis; hipanto 3,5-4 × 3-3,5 $\mathrm{mm}$, urceolado; limbo interno da sépala ca. $2,5 \times 1 \mathrm{~mm}$, membranáceo, triangular, margem ciliada, ápice agudo, face abaxial glabra, dente externo da sépala ca. $1,3 \times 1,5 \mathrm{~mm}$, lineares, ápice agudo-apiculado, face abaxial glabra; pétalas ca. $3,5 \times 2 \mathrm{~mm}$, alvas, oblongo-lanceolado, ápice agudo, terminado por um tricoma glandular; estames 12, levemente desiguais no tamanho, alvos, filete 4,5-5,5 $\mathrm{mm}$ compr., antera 3,5-4 mm compr., atenuada no ápice, conectivo ca. 0,5 $\mathrm{mm}$ prolongado abaixo das tecas, espessado na base, giboso; ovário 1/2-ínfero, metade superior setosa; estilete ca. $9,5 \mathrm{~mm}$ compr. Frutos maduros não vistos.

Material selecionado: Fundo da Antena, 14.III.2012, fr., I.M. Araújo et al. 270 (HUFU).

Material adicional examinado: Minas Gerais, Paraiso selvagem, trilha para Salto Solitário-Delfinópolis, 04.XII.2002, fl., J.N. Nakajima et al. 3349 (HUFU).

Leandra melastomoides ocorre no Brasil, desde o estado da Paraíba até Santa Catarina (BFG 2015), e no Suriname (Wurdack 1976). No PEB parece ser pouco frequente, tendo sido coletada somente em duas áreas de mata seca semidecídua. É facilmente reconhecida pelas flores 6-meras, inflorescência em glomérulos e folhas de base atenuada, com um par de nervuras acródromas suprabasal.

Ilustração em Barberena et al. (2010), Figura 1.

2.4. Leandra quinquedentata (DC.) Cogn. in Martius, Eichler \& Urban, Fl. bras. 14(4): 156. 1886.

Arbustos, ca. 1,5 m alt. Ramos, pecíolo, face adaxial das folhas e hipanto revestidos por tricomas glandulares sésseis, entremeados por esparsos tricomas estrelados. Folhas com pecíolo 0,5-2,5 cm compr.; lâmina 5,5-14 × 1,5-3,5 cm, cartácea, elíptica, ápice acuminado, base atenuada, margem inteira, face adaxial plana, face abaxial revestida por tricomas glandulares sésseis e com tricomas setosos na base das nervuras primárias, 2 pares de nervuras acródromas, par mais interno ca. $4 \mathrm{~mm}$ suprabasal. Tirso ca. $9 \mathrm{~cm}$ compr.; bractéolas ca. $1 \times 0,5 \mathrm{~mm}$, lanceoladas, ápice agudo, glabras. Flores 5-meras, sésseis; hipanto 2-2,5 $\times$ ca. $2 \mathrm{~mm}$, campanulado; sépalas ca. 1 $\times 1 \mathrm{~mm}$, limbo interno da sépala membranáceo, ápice arredondado, margem estrelado-ciliada, ligeiramente maior que o dente externo, dente 
externo da sépala triangular, diminuto, ápice agudo; pétalas ca. $4 \times 1 \mathrm{~mm}$, alvas, lanceoladas, ápice agudo; estames 10, iguais, filete ca. 2,3 $\mathrm{mm}$ compr., antera ca. $2 \mathrm{~mm}$ compr., oblonga, conectivo ca. $0,3 \mathrm{~mm}$ prolongado abaixo das tecas; ovário 1/2-ínfero, glabro; estilete ca. $8 \mathrm{~mm}$ compr. Bagas imaturas ca. $5 \times 2,5 \mathrm{~mm}$, verdes; sementes ca. $1 \times 0,5 \mathrm{~mm}$.

Material selecionado: Lapa do Forno, 19.V.2011, bt., A.R. Rezende et al. 406 (HUFU).

Material adicional examinado: Santa Catarina, Serra do Iquererim, 19.II.1992, fl., J. Cordeiro \& C.B. Poliquesi 907 (HUFU).

Leandra quinquedentata ocorre desde a Bahia até o Rio Grande do Sul (BFG 2015). No PEB ocorre exclusivamente em mata seca semidecídua. A planta apresenta indumento bastante inconspícuo dando a impressão de ser glabra. Esta característica permite reconhecela facilmente, uma vez que as demais espécies de Leandra encontradas no parque apresentam indumento denso.

Ilustração em Barberena et al. (2010), Figura 1.

\section{Miconia Ruiz \& Pav.}

Subarbustos a árvores, indumento variado, ou glabro, ramos subcilíndricos, cilíndricos, quadrangulares, caniculados, alados. Folhas de formatos variados, revestidas por diferentes tipos de tricomas, ou glabras, 1-3 pares de nervura basal e/ou suprabasal; ausência de um par de formicários na base da folha. Panículas simples, de glomérulos ou escorpioides, terminais. Brácteas e bractéolas persistentes ou caducas. Flores 4-5 meras, sésseis ou pediceladas; hipanto campanulado, cilíndrico ou urceolado, piloso ou glabro; sépalas caducas ou persistentes, às vezes limbo interno maior em comprimento que o dente externo, este inconspícuo; corola branca, branco-translúcida, pétalas obovais, oblongoobovais, ovais ou oblongas, ápice arredondado e/ ou obtuso, glabras ou com tricomas glandulares, margem glabra ou ciliado-glandulosa; estames 8-10, cremes, brancos, amarelos ou vináceos, isomorfos, levemente dimorfos ou desiguais no tamanho, antera oblonga, linear, levemente arqueada ou levemente falciforme, 1-4 poro apical ou poro longitudinal amplo a semelhança de uma rima, conectivo prolongado ou não abaixo das tecas, apendiculado ou inapendiculado; ovário 3-4-locular, ínfero ou parcialmente ínfero, glabro; estilete filiforme, glabro, estigma captado, truncado ou punctiforme. Bagas jovens acinzentado-avermelhadas ou verdes, maduras castanhas, nigrescentes ou vináceas, sementes piramidais, ovais ou arredondadas.

3.1. Miconia albicans (Sw.) Triana, Trans. Linn. Soc. Bot. London. 28: 116. 1871.

Arbustos, 0,5-2 m alt. Ramos, pecíolo, face adaxial das folhas jovens, face abaxial da folha, brácteas, bractéolas, hipanto e face abaxial das sépalas revestidos por tricomas aracnóides, persistentes. Ramos subcilíndricos, basais delgados e canescentes, não decorticantes, apicais ferrugíneos. Folhas com pecíolo 0,5-1 cm compr.; lâmina 3,5-13 × 2-5 cm, discolor, cartácea, oblongo-elíptica a oblongo-lanceolada, ápice agudo a acuminado, ou arredondado, base arredondada a subcordada, margem crenulada, face adaxial das folhas adultas glabra, face abaxial canescente, 2-3 pares de nervuras acródromas basais, par marginal inconspícuo. Panículas escorpioides 7-10 cm compr.; brácteas 4,5-5,5 × 1,5 mm, oblongo-lanceoladas, ápice agudo, face adaxial glabra; bractéolas ca. $1 \times$ $0,5 \mathrm{~mm}$, lanceoladas, ápice agudo, face adaxial glabra. Flores 5-meras, sésseis; hipanto 2,5-3 $\times$ 2-2,5 mm, campanulado; sépalas ca. $1 \times 1 \mathrm{~mm}$, triangulares, face adaxial glabra; pétalas 2,5-3 $\times$ 1,5-2 mm, brancas, obovais, ápice arredondado; estames 10, levemente dimorfos, cremes, filete 2-3,5 mm compr., antera 1,5-3,5 mm compr., oblonga, ápice com um poro estreito, conectivo ca. 0,5 $\mathrm{mm}$ prolongado abaixo das tecas, giboso, apêndice ventral ca. 0,5 mm compr., bilobado; estames antessépalos com projeção basal ampla, contínua da região ventral à dorsal; ovário 3-locular, 1/2-ínfero; estilete 3,5-4,5 mm compr., estigma capitado. Bagas imaturas ca. $3 \times 3 \mathrm{~mm}$, acinzentado-avermelhadas; sementes $0,8-1 \times$ $0,6-0,8 \mathrm{~mm}$, piramidais.

Material selecionado: Duas Pontes, 03.X.2011, bt. e fl., D. Marques et al. 287 (HUFU).

Miconia albicans ocorre desde o sul do México e Antilhas até o Paraguai e sul do Brasil (Goldenberg 2009), estando representada em todas as regiões (BFG 2015). No PEB ocorre em cerrado típico, cerrado denso, campo rupestre, mata de galeria e áreas antropizadas. Reconhecida principalmente pelas folhas adultas discolores de face abaxial canescente, revestida por tricomas aracnóides e face adaxial glabra, associadas às inflorescências escorpioides e aos frutos imaturos de coloração acinzentadoavermelhados. Diferencia-se de $M$. stenostachya DC., a qual é bastante similar, por esta apresentar a 
face abaxial da lâmina foliar revestida por tricomas estrelados.

Ilustrações em Matsumoto \& Martins (2005), Figuras 35-37; Martins et al. (2009), Figura 2a-b.

3.2. Miconia alborufescens Naudin, Ann. Sci. Nat. Bot., ser. 3, 16(2): 160. 1850.

Arbustos a arvoretas, 1-2 m alt. Ramos, pecíolo, nervuras da face abaxial das folhas, face abaxial das brácteas e bractéolas, hipanto e dente externo da sépala, revestidos por tricomas estrelados e dendríticos, canescentes a ferrugíneos, persistentes. Ramos cilíndricos, basais delgados, não decorticantes. Folhas com pecíolo $0,5-1,5$ cm compr.; lâmina 3-12 × 1,5-6,5 cm, deflexa a patente, discolor, cartácea, oval, ápice acuminado, base cordada, margem crenulada, face adaxial esparsamente revestida por tricomas estrelados, persistentes ou caducos face abaxial revestida por tricomas aracnóides canescentes a ferrugíneos, persistentes, 3 pares de nervuras acródromas basais, par marginal inconspícuo. Panículas de glomérulos 7-8 cm compr., não escorpioides; brácteas ca. $2,5 \times 1 \mathrm{~mm}$, oblongo-lanceoladas, ápice agudo, face adaxial glabra; bractéolas ca. $1,5 \times 0,5 \mathrm{~mm}$, oblongas, ápice arredondado, face adaxial glabra. Flores 5-meras, sésseis; hipanto ca. 2,5 $\times 2 \mathrm{~mm}$, cilíndrico; limbo interno da sépala ca. $0,5 \times 0,5 \mathrm{~mm}$, branco-translúcido, triangular, dente externo inconspícuo; pétalas 1,5-2,5 $\times$ ca. $1,5 \mathrm{~mm}$, cremes, obovais, ápice arredondado; estames 10, levemente dimorfos, cremes, filete 2,5-3 mm compr., antera ca. $1,5 \mathrm{~mm}$ compr., oblonga, ápice com um poro estreito, conectivo ca. $0,5 \mathrm{~mm}$ prolongado abaixo das tecas, giboso, apêndice ventral ca. 0,2 mm compr., bilobado; estames antessépalos com projeção basal ampla, contínua da região ventral à dorsal; ovário 3 -locular, $1 / 2$ ínfero; estilete ca. 4,5 mm compr., estigma truncado. Frutos não vistos.

Material selecionado: Serra do Carimbo, 05.X.2011, bt. e fl., D. Marques et al. 363 (HUFU).

Miconia alborufescens ocorre desde a Venezuela e Guianas até o Brasil (Martins et al. 2009), estando representada em todas regiões do país, exceto no Sul (BFG 2015). No PEB ocorre em campo rupestre, cerrado rupestre, cerrado típico, sendo comum também em áreas antropizadas, onde forma grandes populações. Pode ser reconhecida pelas folhas frequentemente deflexas, ovais, de base cordada, face abaxial canescente a ferrugínea e panículas de glomérulos.

Ilustração em Martins et al. (2009), Figura 2c.
3.3. Miconia chamissois Naudin, Ann. Sci. Nat. Bot., ser. 3, 16(2): 179. 1851.

Arbustos, 1-1,5 m alt., glabros. Ramos basais quadrangulares delgados, não decorticantes, apicais caniculados. Folhas com pecíolo $0,5-1,2$ cm compr.; lâmina 7,5-12,5 × 4-6,5 cm, patente, discolor, cartáceo-membranácea, ovado-elíptica, ápice agudo, base arredondada a atenuada, margem sinuosa, revoluta, 2 pares de nervuras acródromas, par mais interno ca. $6,5 \mathrm{~cm}$ suprabasal. Panículas 8-13 cm compr., não escorpioides nem em glomérulos; brácteas ca. $1 \times 0,2 \mathrm{~mm}$, lineares, ápice agudo; bractéolas ca. $1 \times 0,5 \mathrm{~mm}$, lanceoladas, ápice agudo. Flores 5-meras; pedicelo ca. 0,3 $\mathrm{mm}$; hipanto 2-2,5 × 1,5-2 mm, campanulado; sépalas ca. 0,5 $\times 0,6 \mathrm{~mm}$, triangulares; pétalas ca. $2 \times 2 \mathrm{~mm}$, brancas, obovais, ápice obtuso; estames 10, levemente dimorfos, cremes, filete ca. 1,3 mm compr., antera ca. 2,5 mm compr., oblonga, ápice com um poro estreito, conectivo ca. $0,5 \mathrm{~mm}$ prolongado abaixo das tecas, apêndice ventral $0,2-0,5 \mathrm{~mm}$ compr., bilobado; estames antessépalos com conectivo giboso no dorso; ovário 3-locular, 1/2-ínfero; estilete 3,5-6,5 mm compr., estigma truncado. Bagas imaturas ca. $4 \times 3,5 \mathrm{~mm}$, esverdeadas; sementes ca. $1 \times 0,5 \mathrm{~mm}$, ovais.

Material selecionado: Carimbo, 25.VI.2012, bt. e fl., I.M. Araújo et al. 284 (HUFU).

Miconia chamissois ocorre na Bolívia (Martins et al. 2009) e em todas as regiões do Brasil (BFG 2015). No PEB ocorre em cerrado antropizado próximo a cursos d'água. Dentre as espécies de Miconia do parque, M. chamissois se destaca por ser a única que se apresenta totalmente glabra. A espécie mais similar é M. elegans Cogn., da qual se diferencia, principalmente, pelas folhas maiores com até $30 \mathrm{~cm}$ compr., enquanto em $M$. chamissois as folhas não ultrapassam $13 \mathrm{~cm}$ de compr.

Ilustração em Matsumoto \& Martins (2005), Figuras 38-40.

3.4. Miconia cubatanensis Hoehne, Anexos Mem. Inst. Butantan, Secc. Bot. 1(5): 139. 1922.

Fig. 2a-b

Arbustos a arvoretas, 0,7-3,5 m alt. Ramos, pecíolo e face adaxial das folhas, revestidos por tricomas estrelados, persistentes ou caducos, face abaxial das folhas, do limbo interno das sépalas e face adaxial das bractéolas revestidos por tricomas estrelados, persistentes. Ramos cilíndricos, basais delgados, canescentes, não decorticantes, apicais ferrugíneos. Folhas com pecíolo 0,5-1,5 cm 
compr.; lâmina 4,5-11 × 0,5-2,5 cm, deflexa, raramente patente, discolor, cartácea, lanceolada a oblongo-lanceolada, ápice agudo a acuminado, base levemente atenuada, margem sinuosa, levemente revoluta, face abaxial canescente a ferrugínea, 2 pares de nervuras acródromas basais, par marginal inconspícuo. Panículas escorpioides 2,5-6 cm compr.; bractéolas ca. $0,8 \times 0,2 \mathrm{~mm}$, lineares, ápice agudo, face abaxial glabra. Flores 5-meras; pedicelo ca. 0,5 mm compr.; hipanto 1,2-2 × 1,5-2 $\mathrm{mm}$, campanulado; limbo interno da sépala ca. 1 $\times 0,5 \mathrm{~mm}$, triangular, dente externo inconspícuo, face adaxial glabra; pétalas ca. 1,5 × $1 \mathrm{~mm}$, brancas, oblongo-obovais, ápice arredondado a obtuso; estames 10, isomorfos, brancos, filete ca. $1 \mathrm{~mm}$ compr., antera ca. $1 \mathrm{~mm}$ compr., oblonga, ápice com um poro estreito, conectivo não prolongado abaixo das tecas, giboso no dorso, inapendiculado; ovário 3-locular, ínfero; estilete ca. 2,5 mm compr., estigma punctiforme. Bagas ca. $3 \times 3 \mathrm{~mm}$, verdes; sementes $1,5-2,5 \times$ ca. $1,5 \mathrm{~mm}$, arredondadas.

Material selecionado: Lapa do Forno, 19.V.2011, fl. e fr., A.R. Rezende et al. 412 (HUFU).

Miconia cubatanensis é endêmica do Brasil, ocorrendo nos estados da Bahia, Mato Grosso, Goiás, Minas Gerais, Espírito Santo, São Paulo, Rio de Janeiro, Paraná e Santa Catarina (BFG 2015). No PEB ocorre em campo rupestre e cerrado rupestre, frequentemente em fendas de rochas. Esta espécie possui características vegetativas bastante variáveis, uma vez que foram observados indivíduos com hábito arbustivo e arbóreo, com folhas de comprimento variando de 4,5-11 cm compr. A forma das folhas e sua posição deflexa nos ramos aproxima esta espécie de $M$. pepericarpa DC., contudo em $M$. cubatanensis a corola apresenta-se pentâmera, enquanto que em $M$. pepericarpa é tetrâmera. A associação de folhas lanceoladas a oblongo-lanceoladas, de ápice acuminado, frequentemente deflexas, bem como face abaxial canescente a ferrugínea, permite o pronto reconhecimento desta espécie.

3.5. Miconia cyathanthera Triana Trans. Linn. Soc. Bot. London 28(1): 137. 1873.

Fig. 2c-e

Subarbustos, 0,5-1,5 m alt. Ramos apicais, pecíolo, face adaxial das folhas jovens, face abaxial das bractéolas e das sépalas e hipanto revestidos por tricomas estrelados, ferrugíneos, persistentes, ramos basais glabros. Ramos subcilíndricos, basais delgados, não decorticantes. Folhas com pecíolo ca. $0,5 \mathrm{~cm}$ compr.; lâmina 1,5-5 ×0,5-1 cm, patente, discolor, cartácea, lanceolada, ápice arredondado, base atenuada, margem inteira ou sinuosa, face abaxial com tricomas caducos, folhas mais velhas com tricomas estrelados apenas nas nervuras, 1 par de nervura acródroma basal. Panículas ca. 1,5 cm compr., não escorpioides nem em glomérulos; bractéolas ca. $1 \times 0,2 \mathrm{~mm}$, lanceoladas, ápice agudo, face adaxial glabra. Flores 5-meras; pedicelo ca. 1,5 mm compr.; hipanto 1-2 × 1-2 mm, campanulado; sépalas ca. $0,7 \times 0,5 \mathrm{~mm}$, triangulares, face adaxial glabra; pétalas ca. 1,5 ×0,8-1 mm, alvas, ovais, ápice arredondado, margem e faces revestidas por tricomas glandulares; estames 10, levemente dimorfos, estames antepétalos com filete ca. $1 \mathrm{~mm}$ compr., antera ca. 0,5 mm compr., oblonga, base cuneada, ápice com dois poros, conectivo ca. 0,2 $\mathrm{mm}$ prolongado abaixo das tecas, apêndice ventral incospicuamente bilobado; estames antessépalos com filete ca. 1,5 mm compr., antera ca. 0,7 mm compr., oblonga, base não cuneada, conectivo ca. 0,3 $\mathrm{mm}$ prolongado abaixo das tecas, apêndice dorsal ca. 0,2 mm compr., apêndice ventral ca. 0,2 mm compr., bilobado; ovário 3-locular, 1/2-ínfero; estilete ca. $3 \mathrm{~mm}$ compr., estigma punctiforme. Bagas ca. $2 \times 1,5 \mathrm{~mm}$, vináceas; sementes ca. 1,5 $\times 1 \mathrm{~mm}$, ovais.

Material selecionado: Córrego de São Miguel, 21.IX.2012, fl., I.M. Araújo et al. 388 (HUFU).

Miconia cyathanthera é endêmica do Brasil, ocorrendo nos estados da Bahia, Goiás e Minas Gerais (BFG 2015). No PEB ocorre exclusivamente em mata de galeria. Esta espécie possui características bastante peculiares, que permitem reconhece-la facilmente das demais, tais como o hábito subarbustivo, as folhas lanceoladas diminutas com até $5 \mathrm{~cm}$ de compr. e as anteras com o dois poros apicais.

3.6. Miconia elegans Cogn. in Martius, Eichler \& Urban, Fl. bras. 14(4): 312. 1888.

Arbustos a árvores, 1-5 m alt. Ramos, pecíolo, folhas, face abaxial das brácteas e bractéolas, hipanto e sépalas moderado a esparsamente revestidos por tricomas estrelados, canescentes a ferrugíneos, persistentes ou caducos. Ramos cilíndricos, basais delgados, não decorticantes. Folhas com pecíolo 1-3,5 cm compr.; lâmina 8-30 $\times 3-11,5 \mathrm{~cm}$, patente, discolor, cartácea, lanceolada a elíptica, ápice acuminado, base arredondada a atenuada, margem sinuosa, levemente revoluta, face abaxial verde claro, 2 pares de nervuras acródromas, par mais interno 3,5-5 mm suprabasal, par marginal inconspícuo. Panículas escorpioides 10-16 cm compr.; brácteas ca. 3,5 × $1 \mathrm{~mm}$; 
bractéolas ca. $1 \times 1 \mathrm{~mm}$, brácteas e bractéolas lineares, ápice agudo, face adaxial glabra. Flores 5-meras; pedicelo ca. 0,5 mm compr.; hipanto $2-2,5 \times 1,5-2 \mathrm{~mm}$, cilíndrico a campanulado; limbo interno da sépala ca. $0,6 \times 0,8 \mathrm{~mm}$, membranáceo, oval, dente externo inconspícuo, ca. $0,5 \times 0,4 \mathrm{~mm}$, triangular; pétalas $1-1,5 \times$ ca. $1,5 \mathrm{~mm}$, alvas, oblongas, ápice arredondado; estames 10 , levemente dimorfos, cremes, filete ca. $1 \mathrm{~mm}$ compr., antera 2,5-3,5 mm compr., oblonga, ápice com um poro estreito; estames antepétalos com conectivo não prolongado abaixo das tecas, giboso no dorso, estames antessépalos com conectivo ca. $0,1 \mathrm{~mm}$ prolongado abaixo das tecas, giboso no dorso, apêndice ventral ca. 0,1 mm compr., bilobado; ovário 3-locular, 1/2-ínfero; estilete ca. $4 \mathrm{~mm}$ compr., estigma truncado. Bagas ca. 3,5 $\times 4 \mathrm{~mm}$, nigrescentes; sementes $1-1,5 \times$ ca. $0,5 \mathrm{~mm}$, piramidais.

Material selecionado: Carimbo, 25.VI.2012, bt. e fl., I.M. Araújo et al. 290 (HUFU).

Miconia elegans é endêmica do Brasil, ocorrendo em todas as regiões do país, exceto no Sul (BFG 2015). No PEB ocorre em mata de galeria, cerrado antropizado e também em campo rupestre, estando na maioria das vezes associada a solos úmidos e a cursos d'água. Caracteriza-se pelas folhas lanceoladas a elípticas, longas com até $30 \mathrm{~cm}$ de compr., pelo par de nervuras acródromas suprabasais e pelos tricomas estrelados canescentes a ferrugíneos, presentes nas folhas, na face abaxial das brácteas e bractéolas, hipanto e sépalas.

Ilustrações em Cogniaux (1886-1888), Figura 63; Martins et al. (2009), Figura 2g-h.

\subsection{Miconia ferruginata DC. Prodr. 3: 181. 1828.}

Arvoretas a árvores, 2-4,5 m alt. Ramos apicais, pecíolo, brácteas, bractéolas, hipanto, face abaxial das folhas, revestidos por tricomas estrelados ferrugíneos, persistentes, ramos basais glabros. Ramos cilíndricos, basais engrossados e robustos, não decorticantes, ramos da inflorescência caniculados. Folhas com pecíolo $1-2,5 \mathrm{~cm}$ compr.; lâmina 7-22 $\times 3-8,5 \mathrm{~cm}$, patente, discolor, subcoriácea, elíptica a oval, ápice agudo, acuminado a arredondado, base cordada, oblíqua a atenuada, margem crenada, face adaxial revestida por tricomas estrelados, persistentes ou caducos 2 pares de nervuras acródromas basais, às vezes mais um par marginal inconspícuo. Panículas escorpioides 12-25 cm compr.; brácteas ca. 10 $\times 1,5 \mathrm{~mm}$, lineares, ápice agudo; bractéolas ca.
$5 \times 1 \mathrm{~mm}$, lineares, ápice agudo. Flores 5-meras, sésseis; hipanto 3,5-4,5 × ca. 3,5 mm, cilíndrico; sépalas inconspícuas, limbo interno truncado, dente externo triangular; pétalas 4-4,5 × 2,5-3,5 $\mathrm{mm}$, alvas, obovais, ápice obtuso; estames 10 , levemente desiguais no tamanho, filete ca. $2,5 \mathrm{~mm}$ compr., antera 3-3,2 mm compr., oblonga, ápice com um poro estreito; conectivo dos estames antessépalos ca. $0,5 \mathrm{~mm}$ prolongado abaixo das tecas, estames antepétalos com conectivo incospicuamente prolongado, apêndice ventral 0,5-0,7 mm compr., biauriculado, apêndice dorsal 0,5-0,7 mm compr.; ovário 3-locular, 1/2-ínfero; estilete ca. 4,5 mm compr., estigma capitado. Bagas 5-5,5 × 4,5-5 mm, ferrugíneas; sementes ca. $1 \times 1,5 \mathrm{~mm}$, piramidais.

Material selecionado: Carimbo, 25.VI.2012, bt., fl. e fr., I.M. Araújo et al. 279 (HUFU).

Miconia ferruginata é endêmica do Brasil, ocorrendo em todas as regiões, exceto no Sul do país (BFG 2015). No PEB ocorre em cerrado típico e campo rupestre, frequentemente formando pequenas populações. Facilmente reconhecida pelos ramos basais engrossados e robustos, revestidos por tricomas estrelados ferrugíneos e pelas longas inflorescências escorpioides.

Ilustrações em Matsumoto \& Martins (2005), Figura 41; Martins et al. (2009), Figura 2i.

3.8. Miconia ibaguensis (Bonpl.) Triana, Trans. Linn. Soc. Bot. London 28(1): 110. 1871.

Arbustos, ca. $2 \mathrm{~m}$ alt. Ramos, pecíolo, brácteas, bractéolas, hipanto e sépalas, revestidos por tricomas estrelados, entremeados por esparsos tricomas setosos, persistentes. Ramos cilíndricos, basais delgados, não decorticantes. Folhas com pecíolo $0,4-0,7 \mathrm{~cm}$ compr.; lâmina 5-15 × 2-5 $\mathrm{cm}$, patente, concolor, cartácea, lanceolada, ápice agudo a acuminado, base atenuada, margem denteado-ciliada, face adaxial revestida por tricomas estrelados, entremeados por esparsos tricomas setosos, persistentes ou caducos, face abaxial esparsamente revestida por tricomas setosos, tricomas estrelados restritos às nervuras, 2 pares de nervuras acródromas, par mais interno ca. $2 \mathrm{~mm}$ suprabasal. Panículas de glomérulos ca. $5 \mathrm{~cm}$ compr., não escorpioides; brácteas ca. $1,5 \times 0,5 \mathrm{~mm}$, lineares, ápice agudo; bractéolas ca. $0,7 \times 0,2 \mathrm{~mm}$, lineares, ápice agudo. Flores 5-meras, sésseis; hipanto ca. 2,5 × 2,5 mm, campanulado; limbo interno da sépala ca. 0,7 $\times 1 \mathrm{~mm}$, membranáceo, largamente triangular, dente externo inconspícuo, terminado em um 
tricoma setoso; pétalas ca. $2 \times 2 \mathrm{~mm}$, brancas, obovais, ápice obtuso; estames 10, dimorfos no tamanho, filetes 1,2-1,7 mm compr., antera 1,7-2 $\mathrm{mm}$ compr., oblonga, ápice com um poro estreito, conectivo não prolongado abaixo das tecas, apêndice ventral 0,2-0,3 mm compr., bilobado; ovário 3-locular, ínfero; estilete ca. $3 \mathrm{~mm}$ compr., estigma capitado. Frutos não vistos.

Material selecionado: Córrego do Marimbeiro, 29.VI.2012, fl. I.M. Araújo et al. 350 (HUFU).

Miconia ibaguensis ocorre desde o sul do México até o Paraguai e sul do Brasil (Goldenberg 2009), onde é amplamente distribuída (BFG 2015). No PEB foi observada em apenas um local, em cerrado antropizado, em beira de estrada. Caracteriza-se principalmente pela face abaxial das folhas esparsamente revestida por tricomas setosos, tricomas estrelados restritos às nervuras, margem denteado-ciliada e inflorescência em glomérulos.

Ilustração em Goldenberg (2004), Figura 7.

3.9. Miconia ligustroides (DC.) Naudin, Ann. Sci. Nat. Bot., ser. 3, 16: 167.1851.

Arbustos a arvoretas, 1,5-2 m alt., canescentes. Ramos, folhas e hipanto, revestidos por tricomas estrelados ferrugíneos, persistentes ou caducos.Ramos subcilíndricos, basais delgados, canescentes, não decorticantes. Folhas com pecíolo 0,2-0,5 cm compr.; lâmina 3-8,5 × 1-3 cm, patente, discolor, cartácea, elíptica, raramente lanceolada a oblonga, ápice agudo a arredondado, base arredondada a levemente atenuada, margem inteira a levemente sinuosa, revoluta, 2 pares de nervuras acródromas basais, par marginal inconspícuo. Panículas 5,5-9,5 cm compr., não escorpioides nem em glomérulos; bractéolas ca. $1 \times 0,3 \mathrm{~mm}$, lineares, glabras, margem ciliado-estrelada, caducas. Flores 5-meras; pedicelo ca. 0,5 mm compr.; hipanto ca. $1 \times 1,3 \mathrm{~mm}$, campanulado; limbo interno da sépala ca. $0,5 \times 0,6 \mathrm{~mm}$, membranáceo, triangular, glabro, dente externo inconspícuo, caduco; pétalas ca. $2 \times$ 1,5 mm, brancas, oblongas, ápice arredondado a obtuso; estames 10, levemente dimorfos, cremes, filete 1,3-1,5 mm compr., antera 1-1,5 mm compr., oblonga, ápice com um poro estreito, conectivo ca. 0,2 mm prolongado abaixo das tecas; estames antepétalos com apêndice dorsal trilobado ca. 0,2 mm compr., estames antessépalos com apêndice dorsal unilobado ca. 0,2 mm compr.; ovário 3-locular, 1/2-ínfero; estilete ca. 1,5 mm compr., ápice espessado, estigma truncado. Bagas 2-3,5 × 2,5-3 mm, vináceas a nigrescentes; sementes ca. $1,2 \times 0,7 \mathrm{~mm}$, ovais.
Material selecionado: Lavrinha, 15.XII.2011, bt., I.M. Araújo et al. 214 (HUFU).

Miconia ligustroides é endêmica do Brasil, ocorrendo em todas as regiões, exceto no norte do país (BFG 2015). No PEB ocorre em campo rupestre, cerrado denso, cerrado típico e em áreas antropizadas. Pode ser reconhecida pela associação das folhas elípticas e estames antepétalos com apêndice dorsal trilobado.

Ilustração em Martins et al. (2009), Figura 2o.

3.10. Miconia paradoxa (DC.) Triana, Trans. Linn. Soc. Bot. London 28: 121. 1871.

Fig. 2f-g

Subarbustos, ca. 0,5 m alt. Ramos, pecíolo, folhas e hipanto revestidos por tricomas estrelados, persistentes ou caducos. Ramos decussadamente achatados e alados, não decorticantes. Folhas com pecíolo 0,5-3 cm compr.; lâmina 4-14 × 2-6 $\mathrm{cm}$, patente, discolor, coriácea, ovada a oblongoovada, ápice obtuso a acuminado, base cordada, margem inteira, hialina, 2 pares de nervuras acródromas basais, par marginal inconspícuo. Panículas 5-11 cm compr., não escorpioides nem em glomérulos; bractéolas ca. $1 \times 0,5 \mathrm{~mm}$, triangulares, ápice agudo, face abaxial com ápice revestido por tricomas estrelados, face adaxial glabra. Flores 4-meras; pedicelo ca. $1 \mathrm{~mm}$ compr.; hipanto ca. 2,5 × 2-2,5 mm, urceolado; limbo interno da sépala inconspícuo ca. 0,3 mm compr., membranáceo, ápice arredondado, glabro, dente externo inconspícuo, ápice agudo; pétalas ca. 2,5 $\times 2 \mathrm{~mm}$, alvas, oblongas, ápice obtuso; estames 8 , isomorfos, filete ca. 2,5 mm compr., antera ca. 2 mm compr., oblonga, ápice com um poro estreito, conectivo não prolongado abaixo das tecas, giboso, inapendiculado; ovário 4-locular, ínfero; estilete ca. 4,5 mm compr., estigma punctiforme. Bagas ca. 5 $\times 4,5 \mathrm{~mm}$, castanhas a nigrescentes; sementes ca. $2 \times 1 \mathrm{~mm}$, piramidais.

Material selecionado: São Miguel, 14.XII.2011, fl. e fr., I.M.Araújo et al. 197 (HUFU).

Miconia paradoxa é restrita ao estado de Minas Gerais (BFG 2015). No PEB ocorre exclusivamente em campo rupestre, nas fendas de rochas. É facilmente distinguida das demais pelos peculiares entrenós achatados e alados, dispostos de forma decussada.

3.11. Miconia rimalis Naudin, Ann. Sci. Nat. Bot., ser. 3,16(2): 238-239. 1850.

Arbustos, ca. 2 m alt. Ramos, pecíolo, hipanto e face abaxial do dente externo da sépala revestidos por tricomas estrelados, persistentes. Ramos 
subcilíndricos, decorticantes na base. Folhas com pecíolo 0,5-1 cm compr., caniculado; lâmina 5-10 $\times 2-4 \mathrm{~cm}$, patente, discolor, cartácea, lanceolada a oval, ápice acuminado a caudado, base arredondada, margem metade superior levemente crenulada, metade inferior inteira, 2 pares de nervuras acródromas basais, par marginal inconspícuo, presença de domácias entre as nervuras na base da folha, moderadamente revestidas por tricomas estrelados,persistentes ou caducos. Panículas 4-6 cm compr., não escorpioides nem em glomérulos; brácteas ca. $3 \times 0,5 \mathrm{~mm}$, oblongas, ápice agudo, brácteas e bractéolas com a face abaxial revestida por tricomas estrelados, face adaxial glabra; bractéolas $1,5-2 \times 0,5 \mathrm{~mm}$, oblongas, ápice agudo. Flores 5-meras, sésseis; hipanto 1,5-2,5 $\times$ ca. $1,5 \mathrm{~mm}$, cilíndrico; limbo interno da sépala ca. $1,3 \times 1 \mathrm{~mm}$, oblongo, dente externo ca. $0,5 \times$ $0,2 \mathrm{~mm}$, triangular; pétalas $2-2,5 \times 1,5-2 \mathrm{~mm}$, alvas, oblongas a obovais, ápice arredondado a obtuso; estames 10, isomorfos, cremes, filete ca. $1,5 \mathrm{~mm}$ compr., antera ca. $2 \mathrm{~mm}$ compr., linear, levemente arqueadas, um poro longitudinal amplo semelhante a uma rima, correspondendo a mais de $90 \%$ do comprimento da teca, conectivo ca. 0,3 $\mathrm{mm}$ prolongado abaixo das tecas, inapendiculado; ovário 3-locular, 1/2-ínfero; estilete ca. 3,5 mm compr., estigma truncado. Frutos não vistos.

Material selecionado: Serra do Carimbo, 05.X.2011, fl., D. Marques et al. 362 (HUFU).

Miconia rimalis é endêmica do Brasil, ocorrendo nos estados da Bahia, Minas Gerais e Espírito Santo (BFG 2015). No PEB ocorre em cerrado típico e campo rupestre. É reconhecida entre as demais espécies de Miconia do parque por ser a única com ramos decorticantes na base e anteras com poro longitudinal amplo semelhante a uma rima. Na maioria das espécies de Melastomataceae as anteras se abrem por um poro apical circular e estreito (Goldenberg et al. 2003).

Ilustrações em Cogniaux (1886-1888), Figura 82; Martins et al. (2009), Figura 2p-q.

3.12. Miconia sclerophylla Triana, Trans. Linn. Soc. Bot. London 28: 119. 1871.

Fig. $2 \mathrm{~h}-\mathrm{i}$

Arbustos a arvoretas, 1,5-3 m alt. Ramos, pecíolo e hipanto, revestidos por tricomas estrelados ferrugíneos a canescentes, persistentes. Ramos subcilíndricos, basais delgados, não decorticantes, apicais caniculados. Folhas com pecíolo 0,5-2,5 cm compr.; lâmina 4,5-16,5 × 2-7,5 cm, patente, discolor, coriácea, elíptica, ápice agudo, base arredondada, margem sinuosa, levemente revoluta, face adaxial das folhas jovens revestidas por tricomas dendríticos, persistentes ou caducos face abaxial revestida por tricomas dendríticos, entremeados por esparsos tricomas estrelados, 2 pares de nervuras acródromas basais. Panículas de glomérulos adensados $8-13 \mathrm{~cm}$ compr., não escorpioides; brácteas e bractéolas cedo caducas. Flores 4-meras; sésseis; hipanto ca. $2 \times 1,5 \mathrm{~mm}$, campanulado; sépalas caducas; pétalas ca. 2,5 × 1,5 $\mathrm{mm}$, brancas, oblongas, ápice obtuso; estames 8 , isomorfos, filete ca. 2,5 mm compr., antera ca. 1,5 $\mathrm{mm}$ compr., oblonga, ápice com um poro estreito, conectivo ca. $0,5 \mathrm{~mm}$ prolongado abaixo das tecas, inapendiculado; ovário 3-locular, 1/2-ínfero; estilete ca. $3 \mathrm{~mm}$ compr., estigma truncado. Bagas imaturas ca. $3 \times 2,5 \mathrm{~mm}$, verdes; sementes ca. $2 \times$ $1,5 \mathrm{~mm}$, ovais.

Material selecionado: Campo do Tiago, 14.XII.2011, bt., I.M. Araújo et al. 201 (HUFU).

Miconia sclerophylla é restrita ao Brasil, ocorrendo nos estados do Ceará, Bahia, Goiás e Minas Gerais (Goldenberg \& Caddah 2015). No PEB ocorre em campo rupestre e, menos frequentemente, em cerradão. Assemelha-se muito a $M$. corallina Spring, com ocorrência também em Minas Gerais (BFG 2015). Wurdack (1976) menciona algumas diferenças entre estas duas espécies, destacando que a principal é o ramo da inflorescência de $M$. corallina com tricomas mais longos e mais densos. Além disso, ao examinar o holótipo de $M$. sclerophylla, Wurdack (1976) esclarece que suas flores são tetrâmeras, o que não foi mencionado por Triana (1871) na descrição original. Miconia sclerophylla pode ser reconhecida pelas inflorescências em glomérulos adensados e flores tetrâmeras.

3.13. Miconia stenostachya DC., Prodr. 3: 181. 1828.

Arbustos, 1-2 m alt. Ramos, pecíolo, face abaxial das folhas, das brácteas e bractéolas, hipanto, sépalas, revestidos por tricomas estrelados canescentes, persistentes. Ramos quadrangulares, basais delgados, não decorticantes, caniculados no ápice. Folhas com pecíolo 0,5-2 cm compr.; lâmina 4,5-12 × 1,5-5,5 cm, patente, discolor, cartácea, oblongo-elíptica a oval, ápice agudo, base arredondada, margem crenulada, face adaxial glabra, 2 pares de nervuras acródromas basais. Panículas escorpioides 6-10 cm compr.; brácteas ca. $4,5 \times 1 \mathrm{~mm}$, triangulares, ápice agudo, face adaxial glabra; bractéolas ca. $0,8 \times$ $0,1 \mathrm{~mm}$, triangulares, ápice agudo, face adaxial 
glabra. Flores 5-meras, sésseis; hipanto ca. $3 \times$ $2 \mathrm{~mm}$, campanulado; sépalas ca. $0,7 \times 1,5 \mathrm{~mm}$, triangulares; pétalas ca. 3,5 × $2 \mathrm{~mm}$, brancas, obovais, ápice obtuso, margem ciliado-glandulosa; estames 10, levemente desiguais no tamanho, filete 1,5-2,5 mm compr., amarelo, antera 2,5-3,5 $\mathrm{mm}$ compr., amarela, posteriormente vinácea, levemente falciforme, ápice com um poro estreito, conectivo não prolongado abaixo das tecas, giboso, apêndice ventral inconspicuamente bilobado; conectivo dos estames antessépalos espessado na base; ovário 3-locular, 1/2-ínfero; estilete ca. 3,5 $\mathrm{mm}$ compr., estigma punctiforme. Bagas imaturas ca. 3,5 $\times 4 \mathrm{~mm}$, verdes; sementes ca. $1 \times 0,5 \mathrm{~mm}$, piramidais.

Material selecionado: Córrego do Marimbeiro, 29.VI.2012, f1., I.M. Araújo et al. 349 (HUFU).

Miconia stenostachya ocorre do sul do México até a Bolívia e Brasil, onde é amplamente distribuída, ocorrendo em todas as regiões do país (Martins et al. 1996; BFG 2015). No PEB é comumente encontrada em cerrado antropizado. Reconhecida pela folha oblongo-elíptica a oval, discolor, com face abaxial canescente e revestida por tricomas estrelados, inflorescências escorpioides e anteras amarelas, posteriormente vináceas.

Ilustração em Rezende (2012), Figuras 1z e 2f.

3.14. Miconia theizans (Bonpl.) Cogn. in Martius, Eichler \& Urban, Fl. bras. 14(4): 419. 1888.

Arvoretas, 1,5-3 m alt. Ramos, pecíolo, folhas e hipanto, esparsamente furfuráceo, persistentes ou caducos. Ramos subcilíndricos, basais delgados, não decorticantes, apicais levemente caniculados. Folhas com pecíolo 0,5-1,5 cm compr.; lâmina 3-9 $\times 1-3,5 \mathrm{~cm}$, patente, discolor, cartácea, elípticolanceolada a elíptica, ápice agudo a acuminado, base arredondada ou atenuada, margem metade superior denticulada, metade inferior inteira, 2 pares de nervuras acródromas basais, par marginal inconspícuo. Panículas 5,5-9 cm compr., não escorpioides nem em glomérulos; raque da inflorescência avermelhada; brácteas ca. $8 \times 1$ $\mathrm{mm}$, oblongo-lanceoladas, ápice agudo, margem revoluta, ciliada; bractéolas $2-3 \times 0,3-0,5 \mathrm{~mm}$, semelhantes às brácteas. Flores 5 -meras; pedicelo ca. $0,5 \mathrm{~mm}$ compr.; hipanto ca. $1,2 \times 1,5 \mathrm{~mm}$, campanulado; limbo interno da sépala ca. $0,6 \times$ $0,5 \mathrm{~mm}$, membranáceo, glabro, dente externo ca. $0,5 \times 0,4 \mathrm{~mm}$, triangular, glabro; pétalas ca. 1,5 $\times 0,8-1 \mathrm{~mm}$, brancas, oblongas a obovais, ápice arredondado a obtuso; estames 10, isomorfos, cremes, filete $2-2,5 \mathrm{~mm}$ compr., antera $1-1,5$ $\mathrm{mm}$ compr., oblonga, ápice truncado, 4-poroso, conectivo ca. $0,2 \mathrm{~mm}$ prolongado abaixo das tecas, apêndice ventral bilobado; ovário 3-locular, 3/4-ínfero; estilete ca. 3,5 mm compr., estigma capitado. Bagas ca. $2 \times 1,7 \mathrm{~mm}$, vináceas a nigrescentes; sementes ca. $0,5 \times 0,3 \mathrm{~mm}$, ovais.

Material selecionado: Trilha após a entrada principal do parque, 17.V.2011, bt., fl. e fr., I.M. Araújo et al. 52 (HUFU).

Miconia theizeans é amplamente distribuída pelas Américas Central (Honduras, Costa Rica, Panamá, Jamaica e Belize) e do Sul (Brasil, Venezuela, Colômbia, Peru e Equador) (Goldenberg 2000). No Brasil, ocorre em todas as regiões, exceto no Norte do país (BFG 2015). No PEB é encontrada em campo rupestre, cerrado típico, cerrado rupestre, mata seca semidecídua, mata ciliar e em áreas antropizadas, sempre associada a cursos d'água. A raque da inflorescência avermelhada, as anteras com 4 poros e as folhas com a metade superior da margem denticulada permitem reconhecer prontamente $M$. theizeans entre as demais espécies de Miconia do PEB.

Ilustração em Silva \& Romero (2008), Figura 2v.

4. Ossaea congestiflora (Naudin) Cogn. in Martius, Eichler \& Urban, Fl. bras. 14(4): 553. 1888.

Subarbustos, ca. $0,5 \mathrm{~m}$ alt. Ramos, face abaxial das folhas, face abaxial das brácteas e dentes externos das sépalas, revestidos por tricomas vilosos. Ramos cilíndricos. Folhas pecioladas; pecíolo ca. $3 \mathrm{~mm}$ compr.; lâmina 2,5-5 × 1,5-3 $\mathrm{cm}$, concolor, elíptica, ápice agudo a arredondado, base arredondada, face adaxial revestida por tricomas setosos, face abaxial com tricomas setosos restritos às nervuras, margem crenado-ciliada, 2-3 pares de nervuras acródromas basais. Cimeiras glomeriformes, axilares; pedúnculo ca. 7,5 mm compr.; brácteas ca. $5,5 \times 3 \mathrm{~mm}$, ovais, face adaxial glabra. Flores 5-meras, sésseis; hipanto 3,5-4 × ca. $2,5 \mathrm{~mm}$, campanulado, revestido por tricomas setosos e vilosos; limbo interno das sépalas ca. 1,5 ×0,7 mm, membranáceo, triangular, glabro, margem ciliada, dente externo ca. $2,5 \times 1$ $\mathrm{mm}$, linear, ápice agudo; pétalas ca. 2,5 × $1 \mathrm{~mm}$, branco-translúcidas, lanceoladas, ápice agudo; estames 10, levemente dimorfos, alvos, glabros, filete ca. $3 \mathrm{~mm}$ compr., antera 2,5-3 mm compr., oblonga, conectivo não prolongado abaixo das tecas, apêndice dorsal $0,5-1 \mathrm{~mm}$ compr., lobado nos estames antepétalos e bilobados nos estames antessépalos; ovário 3-locular, 1/2-1́nfero, ápice 
viloso; estilete ca. $7 \mathrm{~mm}$ compr., filiforme, glabro, estigma punctiforme. Bagas ca. 11,5 × $10 \mathrm{~mm}$; sementes ca. $1 \times 0,8 \mathrm{~mm}$, ovais.

Material selecionado: Fundo da casa dos ventos, 14.III.2012, fr., I.M. Araújo et al. 263 (HUFU).

Material adicional examinado: Minas Gerais, estrada depois do Paraíso perdido em direção ao paredão, região da Represa de Furnas, 8.XII.2005, bt. e fl., R. Romero et al. 7435 (HUFU).

Ossaea congestiflora é endêmica do Brasil, ocorrendo nos estados de Goiás, Minas Gerais e São Paulo (BFG 2015). No PEB é encontrada em campo rupestre, tendo sido observada até o momento apenas em um único local. Reconhecida principalmente pelas inflorescências glomeriformes, axilares, de flores sésseis sustentadas por um pedúnculo longo, com ca. de 7,5 mm comprimento.

Ilustrações em Matsumoto \& Martins (2005), Figuras 70-71; Silva \& Romero (2008), Figuras 3d-e.

5. Tococa guianensis Aubl., Hist. Pl. Guian., vol. 1, p. 438. 1775.

Arbustos a arvoretas, 1,5-3 m alt. Ramos revestidos por tricomas híspidos, entremeados por tricomas glandulares, nós rodeados por uma coroa de tricomas vilosos. Ramos cilíndricos, vináceos. Folhas pecioladas; pecíolo $1-3 \mathrm{~cm}$ compr., mesmo indumento dos ramos; lâmina 6-18 $\times$ 3-10 cm, discolor (no material herborizado), cartácea, elíptica a oval, ápice agudo a acuminado, base arredondada, margem sinuosa, ciliada, esparsamente revestidas por tricomas setosos, entremeados por tricomas glandulares menores, face abaxial com indumento mais abundante nas nervuras, 3 pares de nervuras acródromas basais, par marginal inconspícuo, 1 par de formicários na base da folha 6-12 mm compr. Panículas terminais e laterais; bractéolas 2-4 × 0,5-1 mm, oblongas, ápice agudo, terminando em um tricoma glandular, glabras, margem ciliado-glandulosa. Flores 5-meras; pedicelo ca. 1,5 mm compr.; hipanto 3-3,5 × 2,5-3 mm, cilíndrico a campanulado, glabro, vináceo-esverdeado; limbo interno da sépala membranáceo, ápice arredondado, dente externo ca. 1,5 × 1,5 mm triangular, ápice agudo terminado em um tricoma glandular, glabro; pétalas ca. $5 \times 3,5 \mathrm{~mm}$, róseas, obovais, ápice assimétrico; estames 10, isomorfos, cremes, glabros, filete 4,5-5,5 mm compr., antera 4,5-5,5 mm compr., oblonga, conectivo não prolongado abaixo das tecas, giboso no dorso; ovário 3-locular, 1/2-ínfero, ápice glanduloso; estilete ca. 8,5 mm compr., filiforme, estigma truncado a capitado. Bagas
4,5-5 × 4,5 mm, vináceas; sementes ca. 1,5 ×0,5 $\mathrm{mm}$, piramidais.

Material selecionado: Barris, 26.VIII.2011, fl. e fr., I.M. Araújo et al. 171 (HUFU).

Tococa guianensis ocorre desde o sul do México ao norte e leste da Bolívia, no leste do Brasil e na Guiana Francesa (Michelangeli 2005). No Brasil ocorre em todas as regiões, exceto no Sul do país (BFG 2015). No PEB é encontrada em mata ciliar, campo rupestre e áreas antropizadas próximas a cursos d'água. Facilmente reconhecida pela presença de um par de formicários na base da folha, pelos ramos vináceos e nós rodeados por uma coroa de tricomas vilosos.

Ilustração em Martins et al. (2009), Figura 4i-1.

\section{Agradecimentos}

Aos curadores e técnicos dos herbários BHCB, DIAM, RB, SPF e UEC, a atenção dispensada e os empréstimos e/ou doações de exemplares. Aos participantes das expedições de coletas Danilo Marques, Izabela Moreira, Kleber Resende e Altemar Costa ("seu Duíco"), o apoio. Ao Dr. Renato Goldenberg e ao Dr. José Fernando Andrade Baumgratz, o auxílio nas identificações de Miconia e Leandra, respectivamente. À curadoria do Herbarium Uberlandense, onde estão depositados os espécimes coletados, disponibilizar a estrutura física para o desenvolvimento do presente estudo. Ao CNPq, a bolsa de Mestrado concedida à primeira autora. Ao CNPq (PROTAX, proc. 562290/2010-9) e ao Programa de Pósgraduação em Biologia Vegetal (PPGBV/UFU), o auxílio financeiro para as coletas botânicas e visitas aos herbários. Ao Instituto Estadual de Florestas (IEF), a concessão de licença para coletar no Parque Estadual do Biribiri.

\section{Referências}

Andrino, C.O. 2013. O gênero Paepalanthus Mart. (Eriocaulaceae) no Parque Estadual do Biribiri, Diamantina, Minas Gerais. Dissertação de Mestrado. Universidade de São Paulo, São Paulo. 132p.

Barberena, F.F.V.A; Chiavegatto, B. \& Baumgratz, J.F.A. 2010. Melastomataceae nos remanescentes florestais do Parque Estadual do Ibitipoca, Minas Gerais, Brasil. Boletim de Botânica da Universidade de São Paulo 28: 141-157.

BFG. 2015. Growing knowledge: an overview of Seed Plant diversity in Brazil. Rodriguésia 66: 1085-1113.

Candido, C.P. 2005. A família Melastomataceae na Serra do Cabral-MG: Tribos Melastomeae, Merianieae e Miconieae. Dissertação de Mestrado. Universidade Estadual de Campinas, Campinas. 110p. 
Clausing, G. \& Renner, S.S. 2001. Molecular Phylogenetics of Melastomataceae and Memecylaceae: implications for character evolution. American Journal of Botany 88: 486-498.

Cogniaux, A. 1883-85. Melastomataceae. In: Martius, C.F.P.; Eichler, A.W. \& Urban, I. (eds.). Flora Brasiliensis. Lipsae, Munchen. Vol. 14, pars 3, pp. 1-510.

Cogniaux, A. 1886-88. Melastomataceae. In: Martius, C.F.P. ; Eichler, A.W. \& Urban, I. (eds.). Flora Brasiliensis. Lipsae, Munchen. Vol. 14, pars 4, pp. 1-656.

Franco, I.M.; Costa, F.N. \& Nakajima, J.N. 2014. Richterago (Asteraceae, Gochnatieae) na porção central da Cadeia do Espinhaço em Minas Gerais, Brasil. Rodriguésia 65: 159-173.

Goldenberg, R. 2000. O gênero Miconia Ruiz \& Pav. (Melastomataceae): listagens analíticas e revisão taxonômica da seção Hypoxanthus (Rich. ex DC.) Hook. F. Tese de Doutorado. Universidade Estadual de Campinas, Campinas. 259p.

Goldenberg, R. 2004. O gênero Miconia (Melastomataceae) no estado do Paraná, Brasil. Acta Botanica Brasilica 18: 927-947.

Goldenberg, R. 2009. Melastomataceae: Miconia. In: Martins, S.E.; Wanderley, M.G.L.; Shepherd, G.J.; Melhem, T.S. \& Giulietti, A.M. (eds.). Flora Fanerogâmica do Estado de São Paulo. Instituto de Botânica, São Paulo. Vol. 6, pp. 32-68.

Goldenberg, R.; Teixeira, S.P. \& Martins, A.B. 2003. Anther Dehiscence and Circumscription of Miconia sect. Hypoxanthus (Melastomataceae). Kew Bulletin 58: 195-203.

Goldenberg, R.; Souza, C.M.F. \& Dequech, H.B. 2005. Clidemia, Ossaea e Pleiochiton (Melastomataceae) no Paraná, Brasil. Hoehnea 32: 453-466.

Goldenberg, R.; Penneys, D.S.; Almeda, F.; Judd, W.S. \& Michelangeli, F.A. 2008. Phylogeny of Miconia (Melastomataceae): patterns of stamen diversification in a megadiverse neotropical genus. International Journal of Plant Sciences 169: 963-979.

IEF-Instituto Estadual de Florestas. 2004. Plano de Manejo do Parque Estadual do Biribiri. Vol. 1. IEF, Diamantina. Pp. 1-6.

Kinoshita, L.S; Martins, A.B. \& Rodrigues, K.F. 2007. As Melastomataceae do município de Poços de Caldas, Minas Gerais, Brasil. Hoehnea 34: 447-480.

Marques, D. \& Nakajima, J.N. 2015. Heliantheae s.l. (Asteraceae) do Parque Estadual do Biribiri, Diamantina, Estado de Minas Gerais, Brasil. Hoehnea 42: 41-58.

Martin, C.V.; Little, D.P.; Goldenberg, R. \& Michelangeli, F.A. 2008. A phylogenetic evaluation of Leandra (Miconieae, Melastomataceae): a polyphyletic genus where the seeds tell the story, not the petals. Cladistics 23: 1-13.

Martins, A.B.; Goldenberg, R. \& Semir, J. 2009. Flora de Grão-Mogol, Minas Gerais: Melastomataceae.
Boletim de Botânica da Universidade de São Paulo 27: 73-96.

Martins, A.B.; Semir, J. \& Goldenberg, R. 1996. O gênero Miconia Ruiz \& Pav. (Melastomataceae) no estado de São Paulo. Acta botânica brasílica 10: 267-316.

Matsumoto, K. \& Martins, A.B. 2005. Melastomataceae nas formações campestres do município de Carrancas, Minas Gerais. Hoehnea 32: 389-420.

Michelangeli, F.A. 2005. Tococa (Melastomataceae). Flora Neotropica Monographs 98: 1-114.

Michelangeli, F.A.; Judd, W.S.; Penneys, D.S.; Skean Jr., J.D.; Bécquer-Granados, E.R.; Goldenberg, R. \& Martin, C.V. 2008. Multiple events of dispersal and radiation of the tribe Miconieae (Melastomataceae) in the Caribbean. Botanical Review 74: 53-77.

Michelangeli, F.A.; Penneys, D.S.; Giza, J.; Soltis, D.; Hils, M.H. \& Skean Jr., J.D. 2004. A preliminary phylogeny of the tribe Miconieae (Melastomataceae) based on nrITS sequence data and its implications on inflorescence position. Taxon 53: 279-290.

Montini, I.A. 2013. Melastomataceae no Parque Estadual do Biribiri, Diamantina, Minas Gerais, Brasil: tratamento sistemático e comparação florística. Dissertação de mestrado. Universidade Federal de Uberlândia, Uberlândia. 115p.

Penneys, D.S. \& Judd, W.S. 2011. Phylogenetics and morphology in the Blakeeae (Melastomataceae). International Journal of Plant Sciences 172: 78-106.

Penneys, D.S.; F.A.; Judd, W.S. \& Almeda, F. 2010. Henrietteeae (Melastomataceae): A new neotropical berry-fruited tribe. Systematic Botany 35: 783-800.

Radford, A.E. 1986. Fundamentals of plant systematics. Harper \& Row, New York. 512p.

Renner, S.S. 1993. Phylogeny and classification of the Melastomataceae and Memecylaceae. Nordic Journal of Botany 13: 519-540.

Rezende, A.R. 2012. Sistemática e conservação de Miconia seção Miconia DC. (Melastomataceae) no estado de Minas Gerais, Brasil. Dissertação de Mestrado. Universidade Federal de Uberlândia, Uberlândia. $117 \mathrm{p}$.

Ribeiro, J.F. \& Walter, B.M.T. 2008. Fitofisonomias do bioma Cerrado. In: Sano, S.M.; Almeida, S.P. \& Ribeiro, J.F. Cerrado: ecologia e flora. EmbrapaCPAC, Platina. Pp. 151-212.

Rolim, T.P. 2011. Melastomataceae Juss. no campo rupestre do Parque Estadual do Itacolomi, Minas Gerais, Brasil: relações ecológicas, fitofisionômicas, padrões de distribuição geográfica e comparação florística. Dissertação de Mestrado. Universidade Federal de Viçosa, Viçosa. 104p.

Romero, R. 1996. A família Melastomataceae na Estação Ecológica do Panga, município de Uberlândia, Minas Gerais. Hoehnea 23: 147-168.

Romero, R. \& Martins, A.B. 2002. Melastomataceae do Parque Nacional da Serra da Canastra, Minas Gerais, Brasil. Revista Brasileira de Botânica 25: 19-24. 
Semir, J.; Martins, A.B. \& Chiea, S.C. 1987. Melastomataceae. In: A.M. Giulietti et al. (orgs.). Flora da Serra do Cipó, Minas Gerais: caracterização e lista das espécies. Boletim de Botânica da Universidade de São Paulo 9: 72-78.

Silva, M.A.O. \& Romero, R. 2008. Melastomataceae das Serras do Município de Delfinópolis, Minas Gerais, Brasil. Rodriguésia 59: 609-647.

Souza, M.L.D.R. \& Baumgratz, J.F.A. 2009. Melastomataceae: Leandra. In: Martins, S.E.; Wanderley, M.G.L.; Shepherd, G.J.; Melhem, T.S. \& Giulietti, A.M. (eds.). Flora Fanerogâmica do
Estado de São Paulo. Instituto de Botânica, São Paulo. Vol. 6, pp. 32-68.

Thiers, B. [continuously updated]. Index Herbariorum: a global directory of public herbaria and associated staff. New York Botanical Garden's Virtual Herbarium. Disponível em <http:// sweetgum.nybg. org/ih/>. Acesso em 23 março 2015.

Triana, J. 1871. Les Melastomacées. Transactions of the Linnean Society of London 28: 1-188.

Wurdack, J.J. 1976. Certamen Melastomataceis XXV. Phytologia 35: 1-13.

\section{Lista de exsicatas}

Araújo, I.M. HUFU 52(3.14); 53(3.2); 54(3.7); 60(2.2); 65(1.3); 117(2.1); 135(2.1); 136(2.1); 139(3.6); 140(3.14); 160(2.1); 171(5); 177(3.6); 181(2.1); 183(3.14); 185(2.2); 186(3.12); 187(3.14); 190(2.2); 191(3.1); 192(3.14); 194(1.3); 195(2.2); 196(2.1); 197(3.10); 199(2.2); 200(2.1); 201(3.12); 202(2.2); 208(3.2); 210 (2.2); 211(1.1); 212(1.1);213(3.1); 214(3.9); 216(5); 217(3.13); 218(3.2); 219(3.1); 220(3.1); 221(3.13); 227(1.1); 228(1.3); 235(1.3); 236(2.1); 237(3.12); 245(2.1); 249(3.6); 260(3.12); 262(2.1); 263(4); 270(2.3); 274(2.2); 279(3.7); 284(3.3); 286(1.1); 288(3.14); 290(3.6); 292(2.1); 321(2.1); 324(2.1); 325(3.14); 347(3.5); 349(3.13); 350(3.8); 353(5). Barreto, M. HUFU 9590(2.1). Costa, F.N. SPF 68(3.6). Costa, J.Y. HUFU 111(3.2); 114(3.7). Forzza, R.C. SPF 508(3.9). Furlan, A. SPF 2562(3.6). Giulietti, A.M. SPF 2492(3.2). Hemsing, P.K.B. HUFU 228a(3.6). Hensold, N. SPF 3135(3.10). Leitão Filho, H.F. HUFU 27.513(1.1); UEC 27.456 (1.1); 27.522(2.2); 27.555(3.9). Marques, D. HUFU 163(3.7); 192(3.6); 260(5); 276(3.2); 279(1.3); 282(2.1); 287(3.1); 289(2.1); 295(3.14); 297(2.3); 299(2.1); 300(3.5); 302(2.1); 305(3.4); 313(3.6); 314(5); 335(2.1); 345(3.7); 349(2.1); 351(3.3); 353(5); 362(18); 363(3.2); 368(2.1). Mello, F.N.A. HUFU 270(3.14). Parra, L.R. SPF 103(3.6). Rezende, A.R. HUFU 21(3.2); 92(2.1); 366(3.4); 367(3.6); 383(3.6); 391(3.4); 393(3.12); 394(3.2); 406(7); 408(2.2); 409(3.14); 411(3.4); 412(3.4); 413(3.4); 414(3.4); 415(3.4); 416(3.4). Romero, R. HUFU 8333(3.1); 8442(1.3); 8501(3.12); 8503(2.1). Pirani, J.R. SPF 5597(1.2). Vitta, F.A. HUFU 1054(3.6). Zappi, D.C. SPF 10.630 (3.10). 